\title{
Membangun Nagari Talang Anau melalui Penguatan Kapasitas Aparatur Pemerintahan Nagari
}

\author{
Roni Ekha Putera, Tengku Rika Valentina, dan Rifki Dermawan \\ Fakultas Ilmu Sosial dan Ilmu Politik, Universitas Andalas, Kampus Limau Manis, Padang, 25163. Indonesia \\ E-mail: roniekhaputera@soc.unand.ac.id
}

Keywords: administration, public policy, public services, service innovation

Kata Kunci: administrasi, inovasi pelayanan, kebijakan publik, pelayanan publik

\begin{abstract}
Governance has become an interesting field of study in public administration. The shifting of authority from central government to local government and even to village level becomes a challenge as well as an opportunity for bureaucrats to provide community services. It justifies why understanding of ideal and relevant governance is needed to solve current problems. As a bureaucracy aiming to serve the community, Nagari is expected to be able fulfilling the society's needs. Based on this condition, this initiative was conducted in Nagari Talang Anau, Kecamatan Gunuang Omeh, 50 Kota Regency, West Sumatera Province to solve the problems of limited understanding of local government employees regarding state administration (government). To achieve this goal, the program began by contacting and making confirmation with Wali Nagari and then followed by training and socialization regarding state administration system (government), public policy formulation in Nagari, and community services. The result indicated that there were several problems in Nagari Talang Anau administration, such as limited access to information and technology sector, lack of programs by Lembaga Pemberdayaan Masyarakat (LPM) and insufficient human resources. Based on these problems, the authors and the team members suggested that Nagari administration should focus more on the issue of improving the quality of human resources.
\end{abstract}

\footnotetext{
ABSTRAK

Tata kelola pemerintahan menjadi sebuah kajian menarik dalam studi administrasi publik. Bergesernya kewenangan dari pemerintah pusat ke pemerintah daerah dan diperluas lagi hingga ke tingkat desa menjadi sebuah tantangan dan juga peluang bagi birokrat dalam melayani masyarakat. Kondisi inilah yang perlu pemahaman tentang tata kelola yang ideal dan relevan dalam menghadapi permasalahan yang ada. Sebagai birokrasi terdepan dalam pelayanan maka kelurahan (Nagari) dituntut untuk mampu memberikan kepuasan kepada masyarakat. Berdasarkan kondisi tersebut, kegiatan pengabdian kepada masyarakat dilaksanakan di Nagari Talang Anau, Kecamatan Gunuang Omeh, Kabupaten 50 Kota, Provinsi Sumatera Barat untuk menyelesaikan permasalahan terkait keterbatasan pengetahuan aparat serta masyarakat tentang sistem administrasi negara (pemerintahan). Untuk menghasilkan kegiatan yang bermanfaat dan mencapai tujuan tersebut, maka diperlukan metode dan tahapan berupa komunikasi dan konfirmasi kepada Wali Nagari Talang Anau yang diikuti penyelenggaraan pelatihan dan sosialisasi mengenai sistem administrasi negara (pemerintahan), perumusan kebijakan publik di nagari, dan pelayanan publik. Hasil kegiatan menunjukkan adanya beberapa masalah dalam pemerintahan Nagari Talang Anau seperti keterbatasan sarana bidang teknologi informasi, belum maksimalnya kinerja Lembaga Pemberdayaan Masyarakat, dan kekurangan sumber daya manusia. Berdasarkan permasalahan ini, tim pengabdian kepada masyarakat menyarankan bahwa fokus penyelesaian masalah sebaiknya dimulai dari tahap perbaikan kualitas sumber daya manusia.
} 


\section{PENDAHULUAN}

Sumatera Barat memiliki nama atau istilah sendiri untuk menyebut desa dan dusunnya, yaitu Nagari (desa) dan Jorong (dusun). Nagari didalamnya terdiri dari jorong-jorong yang wilayahnya lebih kecil. Nagari harus memiliki sekurang-kurangnya satu masjid, rumah gadang, rumah adat, sawah ladang, dan tepian. Istilah itu juga dipakai dalam masyarakat di Talang Anau, Kecamatan Gunuang Omeh, Kabupaten Limapuluh kota, Sumatera Barat. Kecamatan Gunuang Omeh memiliki tiga Nagari, yaitu Nagari Pandam Gadang, Nagari Koto Tinggi, dan Nagari Talang Anau.

Nagari Talang Anau berada di daerah dataran tinggi atau daerah darek Kecamatan Gunuang Omeh. Desa ini dikelilingi hutan, gunung, dan jurang. Daerah Talang Anau merupakan ujung Sumatera Barat dan berada di pelosok. Itulah yang membuat lokasi ini sulit dijangkau dengan kendaran roda empat maupun roda dua. Jika dilalui dengan berjalan kaki akan memakan waktu yang sangat lama. Nagari Talang Anau memiliki tiga jorong, yaitu Jorong Talang Anau, Jorong Simpang Padang, dan Jorong Luak Begak. Luas Nagari Talang Anau adalah $1854 \mathrm{Ha}$, di antaranya Jorong Talang Anau 683 Ha, Jorong Simpang Padang 356 Ha, dan Jorong Luak Begak 815 Ha. Nagari ini memiliki penduduk sekitar 2.400 jiwa dan 548 KK, 1.114 jiwa diantaranya adalah penduduk di Jorong Talang Anau.

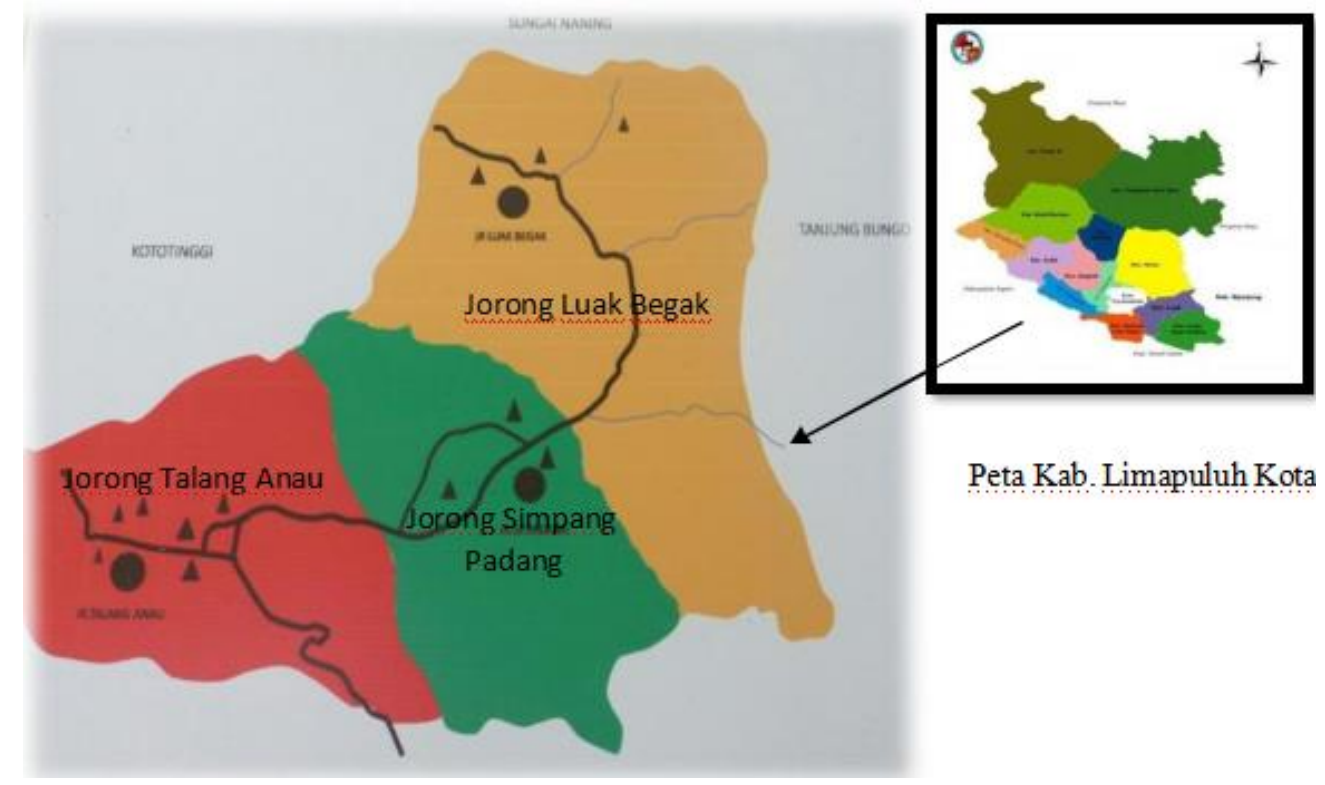

Gambar 1.1 Peta Nagari Talang Anau (Sumber: Paiss, 2016)

Nagari Talang Anau memiliki wali nagari untuk mengurusi pemerintahan, masyarakat, dan nagari. Wali nagari dalam bahasa Indonesia adalah kelurahan. Saat ini Nagari Talang Anau dipimpin oleh Rahaman, S.Pd. Beliau menjabat sebagai wali nagari baru berjalan lebih kurang satu tahun. Sistem pemerintahan yang diterapkan di Nagari Talang Anau adalah menjalankan sistem pemerintahan yang sudah ditetapkan dari pemerintahan pusat.

Selain wali nagari, Talang Anau juga memiliki organisasi badan permusyawaratan, organisasi badan permusyawaratan ini memililiki struktur. Organisasi permusyawaratan ini berfungsi sebagai organisasi masyarakat Talang Anau dan untuk membuat masyarakat terus bersatu dan damai dalam membuat Nagari Talang Anau menjadi daerah yang lebih maju lagi. 


\section{Struktur Organisasi Pemerintahan Nagari Talang Anau}

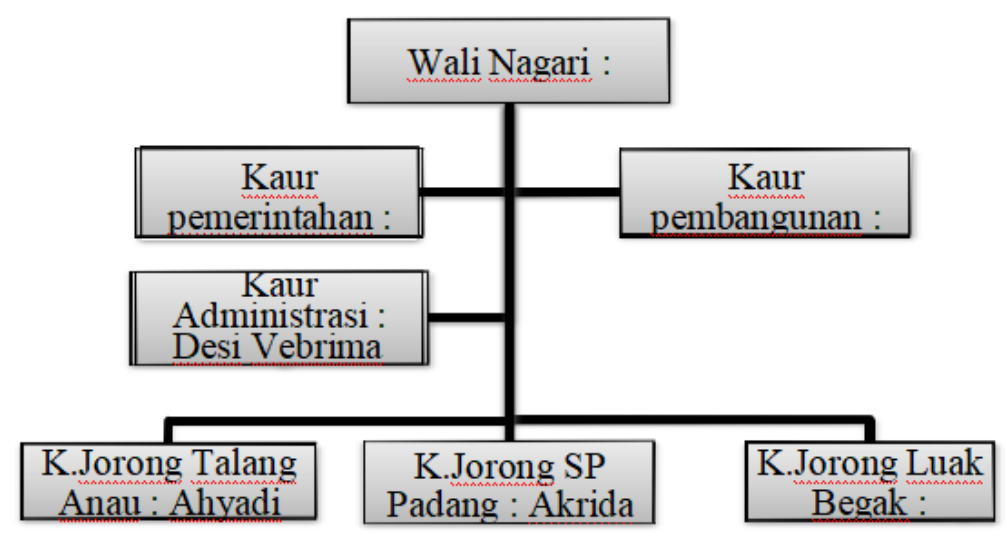

Gambar 2. Struktur Pemerintahan Nagari Talang Anau

(Sumber: Kantor Wali Nagari Talang Anau)

Struktur organisasi badan permusyawaratan Nagari Talang Anau :

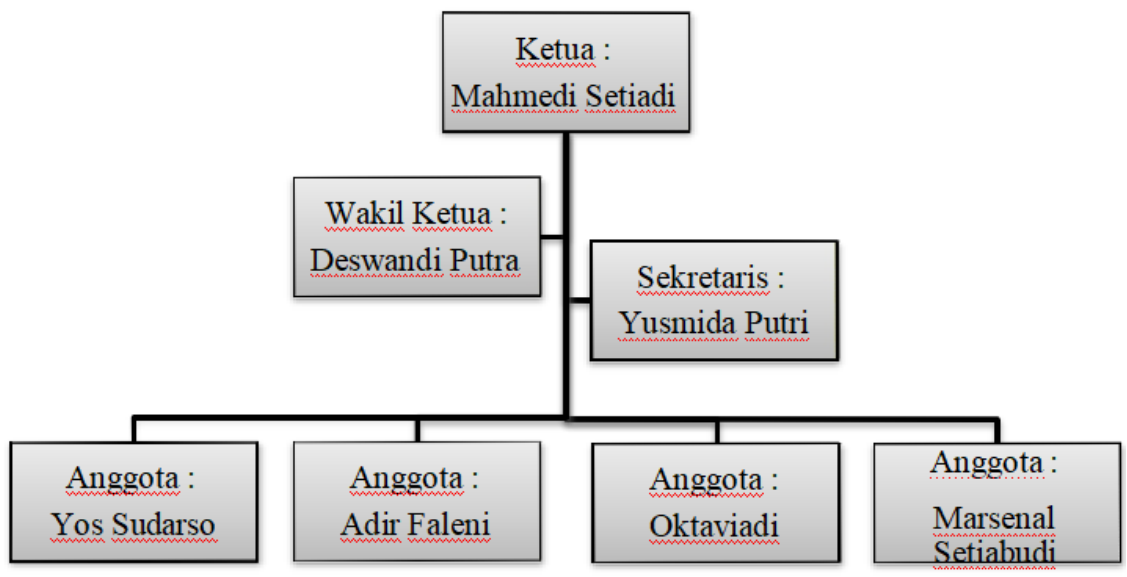

Gambar 3. Struktur Badan Pemusyawaratan Nagari Talang Anau (Sumber: Kantor Wali Nagari Talang Anau)

Sebagai birokrasi terdepan dalam melayani masyarakat maka kelurahan (Nagari) dituntut untuk mampu memberikan kepuasan kepada masyarakat. Administrasi dalam arti sempit bermakna sebagai proses suratmenyurat, pengarsipan dan pembukuan tetapi paradigma tersebut telah lama ditinggalkan. Saat ini administrasi erat kaitannya dengan pengertian dari manajemen yaitu, dua orang atau lebih yang saling terorganisasi dalam satu kesatuan dan saling bekerjasama untuk mencapai tujuan yang telah ditetapkan.

Perkembangan saat ini sistem administrasi pemerintahan dituntut tidak hanya pada efisien dan efektivitas tetapi berupaya untuk lebih sinergitas terutama dari tata kelolanya. Sinergitas tersebut menjadi syarat penting mewujudkan sistem pemerintahan yang ideal karena sistem pemerintahan mulai di tingkat pusat hingga daerah harus saling bekerjasama dan berkomunikasi dengan baik sehingga permasalahan cepat diatasi. Dalam dinamika saat ini sering kali terjadi perbedaan persepsi antara birokrasi di tingkat pemerintahan pusat hingga daerah. Kondisi ini yang menjadi dasar kami selaku civitas akademika Fakultas Ilmu Sosial dan Ilmu 
Politik (FISIP) Universitas Andalas tertarik untuk berbagi ilmu dan bertukar pandangan serta pemikiran mengenai tata kelola sistem administrasi pemerintahan.

\section{METODE}

Untuk menghasilkan kegiatan yang bermanfaat dan mencapai tujuan tersebut, maka diperlukan langkah-langkah sebagai berikut: 1). Menghubungi Wali Nagari Talang Anau untuk mendiskusikan dan meminta izin untuk melaksanakan kegiatan tersebut, serta mengundang aparat nagari untuk saling bertukar informasi dan pengalaman dan perwakilan masyarakat Talang Anau sebagai pengguna layanan. 2). Menyelenggarakan pelatihan dan sosialisasi, yaitu dengan topik atau materi:

A. Sistem administrasi negara (pemerintahan)

B. Perumusan kebijakan publik di nagari

C. Pelayanan publik (prosedur operasi standar, pelayanan prima, dan inovasi pelayanan)

\section{HASIL DAN PEMBAHASAN}

Pengakuan secara yuridis terhadap nagari sebagai kesatuan masyarakat hukum adat di Minangkabau, terutama sejak berlakunya UU No 5 tahun 1979 tentang Pemerintahan Desa, adalah dikeluarkanya peraturan pemerintah daerah Propinsi (Perda Dati 1) Sumatera Barat No 13 tahun 1983 tentang nagari sebagai kesatuan masyarakat hukum adat dalam Propinsi Daerah tingkat 1 Sumatera Barat yang lebih dikenal dengan Perda 13. Menunjuk kepada persyaratan yang harus dipenuhi untuk adanya kesatuan masyarakat hukum adat, maka sebagai suatu persekutuan, nagari agaknya sangat memenuhi syarat dikatakan sebagai masyarakat hukum adat yang otonom. Peryataan ini dapat juga dilihat dari esensi yang terkandung dalam UU nagari seperti yang dikutip oleh A.A. Navis (1984) dan M. Nasroen (1971).

Undang-undang nagari dapat dikatakan sebagai hukum tata negaranya nagari, yang ruang lingkup berlakunya sebatas lingkup nagari yang berstatus otonom. Undang-undang ini tidak memuat pasal-pasal seperti halnya undang-undang dalam pengertian teknis yuridis. UU ini hanya terdiri dari 8 pasal yang saling berpasangan, sehingga kalau dipisahkan akan menjadi 16 pasal (Warman, 2006). Keseluruhan isinya mengatur tentang persyaratan tentang nagari yang mempunyai pemerintahan penuh.

Dengan adanya pemilihan Wali Nagari secara langsung dibeberapa nagari di Sumatera Barat, telah menimbulkan berbagai persoalan terutama dari hal pelaksanaan tata kepemerintahan yang baik di tingkat nagari. Banyak pemimpin nagari dan perangkatnya yang kurang faham atau mengerti cara menjalankan roda pemerintahan. Hal ini disebabkan oleh rendahnya kualitas Sumber Daya manusia Wali nagari dan para perangkatnya. Dari beberapa hasil penelitian yang pernah dilakukan oleh para peneliti Pusat Studi Pemerintah Daerah dan Kebijakan Publik Universitas Andalas (2009) menunjukkan bahwa pelaksanaan tata kepemerintahan yang baik di tingkat nagari kurang berkembang atau berjalan dengan baik dikarenakan lemahnya sumber daya manusia aparatur pemerintahan nagari, sehingga pelayanan yangh diberikan kurang memuaskan. Selain itu banyak dari pada aparatur pemerintahan nagari yang kurang jelas atau faham dengan tugas, pokok dan fungsinya sebagai pelayanan masyarakat

Sehingga dengan perkembangan ilmu pengetahuan dan teknologi sekarang ini para perangkat nagari perlu dibekali dengan pengetahuan dan keterampilan dalam menjalankan roda pemerintahan di tingkat yang paling rendah yaitu di nagari. Sehingga apa yang diharapkan dalam pelaksanaan tata kepemerinatahan yang baik dapat terwujud. 
Kegiatan pengabdian masyarakat dilaksanakan pada hari Kamis, 24 Desember 2020. Kegiatan ini bertujuan secara keilmuwan yaitu pelaksanaan salah satu tugas dan fungsi intitusi perguruan tinggi tentang kontribusi dari segi pemikiran dan teoritis terhadap perkembangan atau permasalahan yang dihadapi masyarakat pada umumnya. Dalam kasus ini permasalahan yang dihadapi masyarakat adalah berkaitan dengan pelayanaan dan pendataan karena menjadi salah satu kebutuhan mendasar masyarakat dalam bagian pengadministrasian yang berbasis online melalui website contohnya, seperti kebutuhan akan identitas baru atau perubahan identitas, kelahiran-kematian, dan banyak lagi yang lainnya.

Kondisi ini yang menuntut perubahan tata kelola administrasi terutama di tingkat nagari menjadi lebih baik. Jadi pengabdian ini dilaksanakan pada Nagari Talang Anau yang dinilai sebelumnya konteks permasalahan yang dihadapi cukup tinggi. Kegiatan dimulai dengan sambutan ketua tim yaitu Dr. Roni Ekha Putera tentang tujuan dan harapan dalam pelaksanaan pengabdian masyarakat. Kegiatan selanjutnya sambutan oleh Wali Nagari Talang Anau, beliau juga nantinya menjelaskan tentang administrasi yang dilakukan di Nagari Talang Anau dan tantangan yang dihadapi kedepannya yang dimoderatori oleh Ilham Havifi, M.Ikom.

Kegiatan pengabdian masyarakat di Nagari Talang Anau tentang sistem administrasi diawali dengan saling diskusi dan penyampaian materi. Sedangkan dari Dr. Roni Ekha Putera selaku ketua tim menjelaskan tata kelola yang baik berkaitan dengan sistem administrasi. Dalam penyampaian oleh ketua tim sering diiringi dengan pertanyaan terutama dari pegawai kelurahan mengenai hambatan yang dihadapi dan bagaimana solusinya. Sedangkan dari anggota tim yang mengikuti kegiatan pengabdian masyarakat ini sangat antusias dan menyimak diskusi karena menambah pemahaman mereka tentang persoalan-persoalan yang dihadapi ditingkat pemerintahan paling bawah yakninya Nagari. Berikut adalah beberapa poin hasil diskusi yang disampaikan perwakilan kelompok masyarakat Nagari Talang Anau.

Tabel 1. Identifikasi Kondisi Nagari Talang Anau

\begin{tabular}{|c|l|l|}
\hline No & \multicolumn{1}{|c|}{ Nama/ Organisasi } & \multicolumn{1}{c|}{ Permasalahan } \\
\hline 1. & $\begin{array}{l}\text { Nofria Erliza, S.Pd } \\
\text { (Kasi Pemerintahan } \\
\text { Nagari Talang Anau) }\end{array}$ & $\begin{array}{l}\text { Adanya keterbatasan sarana dan prasarana pada bidang IT, } \\
\text { dimana hingga desember tahun 2020 pemerintahan nagari } \\
\text { belum memiliki website terkait dengan data } \\
\text { kependudukan. Sehingga hal ini menyebabkan } \\
\text { pemerintahan Nagari Talang Anau belum mampu } \\
\text { melaksanakan pemerintahan berbasis online. Dikarenakan } \\
\text { sistem input data kependudukan masih dilakukan secara } \\
\text { manual. }\end{array}$ \\
\hline 2. & LPM Nagari Talang Anau \\
& $\begin{array}{l}\text { Hingga desember tahun 2020 untuk organisasi LPM dinilai } \\
\text { masih belum memiliki program unggulan. Kemudian } \\
\text { organisasi ini juga dinilai hanya sebagai lambang saja, } \\
\text { karena keberadaan dari organisasi itu sendiri belum dapat } \\
\text { dirasakan oleh masyarakat Nagari Talang Anau. }\end{array}$ \\
\hline 3. & $\begin{array}{l}\text { Fauzi Marjidan } \\
\text { (Wali Jorong Luak } \\
\text { Begak) }\end{array}$ & $\begin{array}{l}\text { Adanya keterbatasan akses sinyal/internet di Jorong Luak } \\
\text { Begak. Kemudian jorong ini juga merupakan jorong } \\
\text { terbanyak penyumbang kasus stunting. }\end{array}$ \\
\hline
\end{tabular}




\begin{tabular}{|c|c|c|}
\hline 4. & Rahman, A.Ma.Pd & $\begin{array}{l}\text { Adanya keterbatasan pengetahuan SDM dari aparatur } \\
\text { pemerintahan nagari dalam merumuskan kebijakan } \\
\text { berupa peraturan nagari (Pernag), sehingga dengan } \\
\text { adanya fenomena tersebut maka pihak nagari } \\
\text { membutuhkan arahan dan pendampingan dalam proses } \\
\text { penyusunan kebijakan tersebut. }\end{array}$ \\
\hline 5. & $\begin{array}{l}\text { Yarman, S.Sos } \\
\text { (Sekretaris Nagari) }\end{array}$ & $\begin{array}{l}\text { Pada tahun } 2020 \text { pemerintahan nagari sedang melakukan } \\
\text { pembangunan PAMSIMAS, namun hingga saat ini terkait } \\
\text { dengan kebijakan pengelolaan atau pemanfaatan fasilitas } \\
\text { pamsimas belum ada hingga saat ini. Hal ini berkaitan } \\
\text { dengan terbatasnya kemampuan aparatur pemerintahan } \\
\text { nagari dalam merumuskan kebijakan. }\end{array}$ \\
\hline 6. & $\begin{array}{l}\text { Desi Vebria Ningsih } \\
\text { (Kasi Administrasi } \\
\text { Keuangan Nagari Talang } \\
\text { Anau) }\end{array}$ & $\begin{array}{l}\text { Adanya keterbatasan pemahaman dan pengetahuan dari } \\
\text { Kasi sendiri pada sistem pembukuan anggaran dan } \\
\text { penggunaan aplikasi pengelolaan anggaran. }\end{array}$ \\
\hline 7. & $\begin{array}{l}\text { Akrida Andespa } \\
\text { (Wali Jorong Simpang } \\
\text { Padang) }\end{array}$ & $\begin{array}{l}\text { Saat ini wali jorong merasa bahwa terkait anggaran hanya } \\
\text { berasal dari dana desa saja, sehingga hal ini menjadi } \\
\text { keterbatasan bagi nagari dalam membangun dan } \\
\text { memperbaiki infrastruktur. Terutama pada Jorong } \\
\text { Simpang Padang. }\end{array}$ \\
\hline 8. & $\begin{array}{l}\text { Bundo Kanduang Nagari } \\
\text { Talang Anau Kec. } \\
\text { Gunung Omeh }\end{array}$ & $\begin{array}{l}\text { Membutuhkan arahan dan pendampingan dalam } \\
\text { merumuskan program yang akan di buat oleh Bundo } \\
\text { Kanduang dalam melakukan pemberdayaan masyarakat. } \\
\text { Karena pihak Bundo Kanduang merasa bahwa selama ini } \\
\text { kontribusi pihak nagari belum dapat dirasakan. }\end{array}$ \\
\hline 9. & $\begin{array}{l}\text { Aspel Musli } \\
\text { (Kasi Kesejahteraan dan } \\
\text { Pelayanan Nagari Talang } \\
\text { Anau) }\end{array}$ & $\begin{array}{l}\text { Adanya keterbatasan sumber daya manusia dalam } \\
\text { melakukan pengembangan dibidang pertanian, perikanan, } \\
\text { dan peternakan sehingga ketiga bidang tersebut hingga } \\
\text { saat ini dinilai belum mampu berkembang. Harapanya jika } \\
\text { ketiga bidang tersebut dapat dikembangkan dengan baik, } \\
\text { maka terkait dengan pemasukkan nagari dapat diperoleh } \\
\text { dari ketiga bidang tersebut tidak hanya memanfaatkan } \\
\text { dana desa saja untuk membangun nagari. }\end{array}$ \\
\hline
\end{tabular}

Tanpa terasa penyampaian diskusi telah dua jam berlangsung dengan menggali beberapa permasalahan yang dihadapi oleh pemerintah nagari terutama dalam kinerja aparatur nagarinya. Tanya jawab yang cukup antusias antara masyarakat dan peserta FGD sehingga memunculkan beberapa rencana kegiatan lanjutan dari tim pengabdi terhadap permasalahan yang dihadapi di Nagari Talang Anau, ditutup dengan kesimpulan. Selanjutnya Setelah terselengaranya serangkaian kegiatan Pengabdian Masyarakat, maka tiba pada akhir acara yaitu penutupan kegiatan. Acara ini ditutup dengan penyerahan plakat secara simbolis oleh ketua tim, Dr. Roni Ekha Putera kepada Wali Nagari Rahaman, S.Pd. dan selanjutnya secara resmi ditutup oleh panitia kegiatan pengabdian kepada masyarakat. 


\section{KESIMPULAN}

Dari hasil diskusi dalam kegiatan pengabdian kepada masyarakat dalam keberlanjutan membantu nagari membangun ada beberapa keharusan yang segera dilakukan untuk memecahkan permasalahan yang ada di nagari Talang Anau, di antaranya adalah pembuatan dan pelatihan pengelolaan situs web untuk data kependudukan, pelaksanaan pelatihan terkait peningkatan sumber daya manusia bagi aparatur pemerintahan nagari dan masyarakat dalam bidang pertanian, peternakan, perikanan, dan pariwisata serta proses pembuatan peraturan nagari. Tim pengabdian kepada masyarakat merekomendasikan aparatur nagari Talang Anau agar berfokus kepada perbaikan sumber daya manusia yang ada dalam pemerintahan nagari dengan harapan semakin baiknya sumber daya manusia maka pengelolaan aset yang ada di nagari dapat dikelola dengan lebih profesional.

\section{DAFTAR PUSTAKA}

Nasroen, M. 1971. Dasar Falsah Adat Minangkabau. Jakarta: Bulan Bintang.

Navis, A.A.. 1984. Alam Takambang Jadi Guru, Adapt Dan Kebudayaan Minangkabau. Jakarta: PT Graviti Press.

Paiss, N.R. 2016. Talempong Batu di Nagari Talang Anau, Kecamatan Gunuang Omeh, Kabupaten Lima Puluh Kota, Provinsi Sumatera Barat: Analisis Fungsi Musik dan Pola Ritem. Skripsi.

Putera, R.E. 2020. Laporan Pengabdian Kepada Masyarakat Skim Program Kemitraan Masyarakat Membantu Nagari Membangun. Laporan Pengabdian Kepada Masyarakat.

Warman, Kurnia. 2006. Ganggam Bauntuak Menjadi Hak Milik: Penyimpangan Konversi Hak Tanah Di Sumatera Barat. Padang: Andalas University Press. 